\title{
Social identities in the policy process
}

\author{
Johanna Hornung $^{1}$ (D) $\cdot$ Nils C. Bandelow ${ }^{1}$ (D) $\cdot$ Colette S. Vogeler ${ }^{1}$ (D)
}

Published online: 21 November 2018

(c) The Author(s) 2018

\begin{abstract}
This paper introduces social identity theory and self-categorization theory to policy process research. Drawing from the prominent and widely acknowledged psychological social identity approach, it develops the theoretical concept of social identities in the policy process (SIPP) and advances the understanding of policy actors' behavior. Compared to psychological foundations of existing theories of the policy process, the social identity approach emphasizes the importance of social group membership for forming common views on policy content and shaping policy actors' behavior as beneficial to the in-group. Policy actors thus act in accordance with their salient social identity. This salience is dependent on the strength of a social identity, determined by the feeling of belonging, positive evaluation, and emotional bond to a group. Additionally, social identities are moderated by internal and external factors. SIPP distinguish three levels of analysis, ranging from the psychological microlevel concerned with individual behavior and preferences, over the socio-psychological mesolevel of intra- and intergroup dynamics toward a macroperspective of general types of social identities. In policy subsystems, five such types appear relevant: organizational identities, local identities, sectoral identities, demographic identities, and informal identities. By integrating SIPP into the analytical categories of theories of the policy process, this paper calls for a future research agenda establishing a further theoretical lens for a better understanding of policy processes.
\end{abstract}

Keywords Social identity theory (SIT) - Self-categorization theory (SCT) · Advocacy coalition framework $(\mathrm{ACF}) \cdot$ Multiple streams framework $(\mathrm{MSF}) \cdot$ Social groups $\cdot$ Identity salience

Johanna Hornung

j.hornung@tu-braunschweig.de

Nils C. Bandelow

nils.bandelow@tu-braunschweig.de

Colette S. Vogeler

colette.vogeler@tu-braunschweig.de

1 Comparative Politics and Public Policy, University of Braunschweig, 38106 Brunswick, Germany 


\section{Introduction}

Theories of the policy process mostly originate from assumptions about the behavior of policy actors. These assumptions range from utility maximization (Rational Choice Theory) over belief systems (advocacy coalition framework), to ambiguity (multiple streams framework) (Nohrstedt and Olofsson 2016; Herweg et al. 2017; Weible and Sabatier 2017; Jenkins-Smith et al. 2017; Bandelow et al. 2017). Although theories that focus on individual actors make use of psychological concepts, the existing theories of the policy process do not yet systematically include psychological models of choice (Cairney and Weible 2017). One of the most prominent and acknowledged psychological theories are the social identity theory (SIT) (Tajfel 1982a) and the related Self-Categorization Theory (SCT) (Turner et al. 1987) that are subsumed under the label of the social identity approach (Haslam 2014). Up to now, researchers of policy studies only marginally refer to the SIT (Boydstun and Glazier 2013; Miles 2016; Gilad and Alon-Barkat 2017), when in fact the social identity approach provides the possibility to explain preferences and behavior of policy actors, to enhance existing theories with regard to the model of the individual and to present a tool for political advisors (Winterich et al. 2012).

The social identity approach supposes that actors' behavior is substantially shaped by intergroup relations and group identification (Tajfel 1974; Jenkins 2014). Its applications touch upon a variety of research fields, including organizational and management research (Ashforth and Mael 1989; Ellemers et al. 2004; Steffens et al. 2014), marketing and sponsorship (Grohs et al. 2015), party politics (Greene 1999; Bartle and Bellucci 2009; Bonneau and Cann 2013), intercultural studies (Sides and Citrin 2007; Adams and van de Vijver 2015), international relations (Kakachia and Minesashvili 2015), social movements (Simon and Klandermans 2001; Polletta and Jasper 2001; Subašić et al. 2008; van Zomeren et al. 2008; Thomas et al. 2009; Klandermans 2014; Naples and Bickham Mendez 2015), education (Mavor et al. 2017; Reynolds et al. 2017) and gender studies (Wang and Dovidio 2016). Those are parts or related fields of research on the policy process but still, there is a need for integrating the social identity approach into policy process theories. In the hitherto four editions of the influential "Theories of the Policy Process," there are only few hints to (social) identity (Sabatier and Jenkins-Smith 1999). None of the theories on which this paper grounds, neither SIT nor SCT, are referred to in these overviews yet (Sabatier 1999, 2007; Sabatier and Weible 2014; Weible and Sabatier 2017). Building on the extensive groundwork of related fields already integrating the social identity approach, this paper starts to fill this gap and proposes a more explicit adoption in the form of social identities in the policy process (SIPP).

The presented theoretical perspective is suitable to answer research questions concerned with the dynamics in the policy process, such as the conditions under which identities become salient in the policy process, the mechanisms behind individual identification with policy-concerned groups, the extent of coordinated action across policy-concerned groups, the effect of salient policy-concerned identities on policy preferences, and the eventual influence of social identities in decision-making processes. General types of identities that are assumed to be pertinent to the policy process are organizational identities (Cole and Bruch 2006), sectoral identities (Hassenteufel et al. 2010), local identities (Bonaiuto et al. 2002), demographic identities (Béland 2017), and informal identities (Walsh 2004).

By reviewing the state of the art regarding the social identity approach in general and its applications to political science in particular, the following section outlines the facets of the social identity approach that later are connected to policy process research. Section "Social 
identities in the policy process (SIPP)" consequently introduces SIPP as a new theoretical concept to the policy process by deriving hypotheses from the previously elaborated state of the art and distinguishes SIPP from established theories of the policy process. With regard to a macrolevel of analysis, this part also discusses five general types of social identities relevant to the policy process. Despite the demarcation from other frameworks, SIPP may likewise complement research that uses different theoretical perspectives, as section "Integrating SIPP: past and future research" outlines and thus opens avenues for further research. Finally, a conclusion summarizes the proposed theoretical advancement.

\section{The social identity approach}

Social identity theory (SIT) is credited to Henri Tajfel (1974), who developed the theory in line with his research on-among other foci-effects of minimal categorization, intergroup relations, and social comparison. Minimal categorization implies that human beings tend to facilitate the world through categorization, and thus categorize themselves and others. An important point of reference for categorization are social groups, which each consist of two or more people who define themselves as a member of the social group and thus share a common social identification (Turner 1982). Social identification, meaning a person's identification with a social group, encompasses three components: a cognitive, an evaluative, and an affective (Van Dick 2001). Once an individual identifies with a group, it takes over the social identity connected to it. The individual from then on distinguishes itself from others by this categorization. Two main motivations guide individuals in their group identification: the wish for sameness and the wish for distinctiveness (Hogg et al. 2017), stemming from optimal distinctiveness theory (Brewer 1991; Leonardelli et al. 2010).

Furthermore, individuals strive for positive social identity, that is evaluating their social groups positively in comparison with others (Hogg et al. 2017). Tajfel and his student Turner developed the SIT accordingly to a "Social Identity Theory of Intergroup Behavior" (Hogg et al. 2004). They referred to intergroup behavior using the definition of Sherif $(1966,12)$ : "Whenever individuals belonging to one group interact, collectively or individually, with another group or its members in terms of their group identification, we have an instance of intergroup behavior" (Sherif 1966, 12). In this view, however, Tajfel (1982b) determined two necessary conditions for intergroup behavior, an internal and an external. While the existence of a group is dependent on the internal condition of group identification or social identification, comprising the individual awareness of group membership, value connotations associated with this membership awareness and an emotional component associated with the two, intergroup behavior necessitates also an external consensus concerning the existence of the group. Further research on intergroup behavior revealed that the social identification with a group resulted in pro-group behavior. Individuals favored in-group members over out-group members in the distribution of resources (Turner 1982). This finding proposes that individuals act in accordance with the guiding principle of achieving a benefit for the own social group. Salient identities bring about biases toward in-group against the out-group, affecting not only evaluative but also distributional and perceptional dimensions (Turner et al. 1987).

While SIT regards social identity as a distinct component of the self-concept that feeds on the dimensions of social identification (subjective belonging, evaluation, and emotional attachment), SCT postulates that "individuals categorize themselves on different levels" (Van Dick et al. 2005): a personal level that refers to the unique individual, a group level 
that refers to the individual as a member of a social group distinct from other social groups, and on a superordinate level on which the individual distinguishes itself as a human being from other species (Van Dick et al. 2005). Consequently, whether a social identity is influential in a given situation is dependent not only on the social identification but also on the context and the salience of a social identity in the given context. Salience is triggered both by accessibility and fit of a social identity, whereas accessibility means the extent to which an individual perceives this social identity as relevant due to personal meaning and significance. Accessibility may be partly operationalized by assessing the level of social identification (i.e., the strength of a social identity). Since social identification is based on the awareness of membership, positive evaluation, and positive emotional bond (Tajfel 1982b), the degree of an individual's group identification - that is the degree of the mentioned dimensions - determines the strength of the individual social identity (Ellemers et al. 1999). Social identities are also supposed to be stronger when they have a long history and when policy actors have regular contact with others sharing the same social identity (Cole and Bruch 2006; Haslam et al. 2011a, b; Westfall et al. 2015; Suhay 2015).

Fit, complementarily, refers to the extent to which a categorization matches the stimulus reality (Oakes et al. 1991). This can take a normative and a comparative dimension. On the former dimension, normative fit implies that an individual's expectation regarding category members' stances on content-related issues are reflected by its actual observation of similarities and differences between those members. On the latter dimension, comparative fit means that a social identity is more likely to become salient if the individual perceives the differences between members of this social group as smaller than differences between these members and members of other social groups (Haslam et al. 1999; Haslam 2001; Van Dick et al. 2005).

Concerning context, a specific policy may trigger a specific social identity, e.g., a debate on abortion may make the demographic social identity more salient than the organizational social identity (Haslam et al. 1999; Transue 2007). Likewise, a social identity may be more salient when the social identity is stronger. This seems tautological, but in fact it is not: A salient identity is the social identity that is perceived by an actor in a specific situation as the guiding principle of action. A social identity may be weak but still be salient in a specific situation due to the context. Nevertheless, the strength of a social identity also influences how often it becomes salient.

Since every individual possesses several social identities, some of which it will feel stronger attached to than to others, social identity conflict may occur (Hirsh and Kang 2015). Multiple group membership of an individual may thus have a diverse effect on the subjective representation, as the degree of overlap of these multiple identities determines the degree of social identity complexity: Individuals can converge their cross-cutting identities to one identity (intersection), decide on one superordinate identity to follow (dominance), have a salient identity depending on context (compartmentalization) or merge multiple social identities, which leaves blurred lines between in-group and out-group identification (merger) (Roccas and Brewer 2002). Consequently, different situations and context (including previously elaborated fit and accessibility) influence salience of social identities and with it individual behavior, but this behavior is equally dependent on the type of an individual's multiple identities and the associated ability to integrate beliefs and values of conflicting identities. Furthermore, the behavior of an individual in a given situation is always dependent on the identity structure of his/her different social identities and the level of inclusiveness of each identity. This process of one (individual or group) identity being activated over the other is described as functional antagonism (Liu and Hilton 2005; Hornsey 2008). 
A parallel path of research on the importance of social identities developed in political science (Campbell et al. 1960; Miller 1986). Since then, the social identity approach was applied in research on partisanship, arguing that voting for a party is essentially dependent on group identification (Kim 2017). Partisanship is a type of social identity formed by childhood socialization and other social group memberships, which results in attachment to a party and corresponding behavior (e.g., voting) (Bartle and Bellucci 2009; Greene 2004). Depending on the salient (partisan) identity, individual preferences and behavior diverge (Unsworth and Fielding 2014). Further work on this subject showed that party identification is a predisposition rather than a consequence of core values and attitudes (Goren 2005; Dancey and Goren 2010). Recent research emphasizes the influence of peer networks on the salience of partisan as social identities (Parsons 2015). Posner (2017) investigated social cleavages as foundation of social identities and their political salience for decisionmaking, to connect to the established cleavage theory in Europe (Lipset and Rokkan 1967). Already some 15 years ago, Huddy (2001) called for analyzing which real-world identities matter for political phenomena and how their respective strength and salience in certain situations may be explained.

The above deliberations on social identities predominantly concern the microlevel of action. As the social identity approach stems from psychology, social identification is at first an individual process. Taking it one step further, a mesolevel of analysis regards intergroup relations (Tajfel 1974). This perspective also looks at intra-group dynamics, such as a social cohesion model that assumes that group structures with assigned group roles emerge (Turner 1982) and has a rather sociological than psychological nature. Apart from psychology, the concept of group leadership has found entrance into economics, particularly organizational and marketing studies (Woisetschläger et al. 2008). Collective group values are said to be handed down hierarchically from the group leader to the group members (Ellemers et al. 2004; Steffens et al. 2014), as exemplified by the identity transfer model (Wieseke et al. 2009). Alternatively, a "new psychology of leadership" (Haslam et al. 2011a, b) opposes the traditional image of top-down group leaders that rest on compliance but rather uses the idea of group leaders as primus inter pares, who does not impose a social identity but takes part in shaping it collectively-though in his sense. Dialogue among group members and understanding the group members' values is important for successful leadership. He who manages to make the group believe that his agenda and preferences are part of their social identity manages to lead a group effectively. No matter which assumption is taken, leadership presents an important determinant of the development of a social group and the collective group values (Epitropaki et al. 2017). Collective group values are different from individual values as they are usually those that are the distinct characteristic for distinguishing the in-group from other out-groups, e.g., pro-environmental attitudes (Fielding and Hornsey 2016). In contrast, individual values originating from a social identity do not need to be the most distinguishing group value but may be any kind of value coined by the social group. Accordingly, an analysis of the formation of collective attitudes and behavior is possible. Collective identity may equally be a driver of radicalization in a politicized conflict about power structures (Klandermans 2014). Thus, the concept of collective identity is frequently used in social movement research (Polletta and Jasper 2001).

Regarding group dynamics, Richter et al. (2006) analyzed in what way dual identities (coexisting social group membership within an organization through membership in a work group and parallel membership in the superordinate organization) affect intergroup relations on the work group level. Essential in this correlation is the role of boundary spanners as those group members that cultivate frequent contact with out-groups. In case of a 
high identification with the superordinate social group and lower identification with the work group to which they belong, they were able to effect productive intergroup cooperation. Thus, there might exist amicable groups and between-group cooperation under certain political circumstances that generate attention to a superordinate identity (e.g., in parliamentary democracies, the opposition might experience a specific between-group cooperation between parties with originally distinct agendas, as the opposition could present a superordinate social identity). A superordinate identity can equally be a product of personal identities firstly contributing to subgroup social identities that finally conduct the superordinate organizational identity to enhance organizational outcome. This process is prominently referred to as the ASPIRe (Actualizing Social and Personal Identity Resources) model (Haslam et al. 2003; Peters et al. 2013). Similarly, research in organizational psychology has problematized mergers between companies against the backdrop of original group identification (Ullrich and Van Dick 2007). With social identification being a central factor of success for mergers, this finding can be transferred to the political sphere: Social groups may merge and develop a shared social identity or split because intra-group social identities diverge. In party politics, there exist several examples of party mergers or splits (such as the Liberal Democrats in Great Britain) that may be analyzed through the theoretical lens of social identification. Likewise, new groups may emerge; groups may develop and change, or decline. While the question why actors in the policy process involve in coordinated action to pursue common policy goals is at the center of several perspectives, integrating the social identity approach may also contribute to their respective research interest. Hence, the likeliness of collaboration among policy actors, both individual and collective, can be enhanced through social identification.

Building on this vast literature of social psychological research, the upcoming section transfers the insights from social psychology to policy process research. In particular, it formulates specific hypotheses that combine the results from social psychology with the policy process and identifies different types of social identities that can be observed on a macrolevel of analysis. These do neither correspond exactly to each individual social identity in the policy process, nor do they shed light on intra- or intergroup relations. On the contrary, they indicate general types of social identities, and thus present the unique contribution of SIPP to the existing research on social identities. The following section thus is explicitly devoted to these types of social identities by assessing shared characteristics of policy actors, which may suffice to build common behavior and views (Light 2015).

\section{Social identities in the policy process (SIPP)}

In public policy analysis, the distinction between theories and frameworks is subject to a prominent discussion (Schlager and Weible 2013). This paper's understanding is that introducing social identities in the analysis of policy processes may serve to supplement existing frameworks or be applied as a theoretical perspective on its own to shed light on actors' behavior, preference formation, and decision-making processes in politics. An integration of the social identity approach into policy analysis grounds in Lasswell's (1970) wellknown claim that policy sciences are multidisciplinary and require taking into account a broad range of explanations. Table 1 pins down SIPP as a theoretical concept according to the classifying criteria used to distinguish the most recent theories of the policy process. With this classification, it is integrated into the established categories of the most 
Table 1 Classifying social identities in the policy process (SIPP). Source: Categories derived from Heikkila and Cairney (2017)

Comparative criterion

Social identities in the policy process (SIPP)

Scope

Policy actors' orientation and interaction

Level of analysis

Social groups, individuals, and subsystems

Shared vocabulary and language

Key concepts: social identity, social group, five categories of social identities on the macrolevel

Assumptions

Model of the individual

Explicitly defined based on social identity approach

Individual as a member of social groups with social identities constraining behavior

Relationships among key concepts

Extent of publications

Hypotheses at microlevel, mesolevel, and macrolevel on the influence of salient social identities on actors' behavior and policy outcome

Extensive research on social identity approach in psychology, some few references in Politics and International Relations

Tested in multiple contexts and/or with multiple methods

Psychologically tested on the mesolevel and microlevel, methods are predominantly experimental, for policy studies both qualitative (on the micro- and mesolevel) and quantitative (on the macrolevel) methods applicable

Shared research protocols, methods, approaches

Social Identity Lab, directed by Michael Hogg (http:// www.socialidentitylab.com)

Change or adaptation to the theory over time

Actors making choices

Development of theory in psychological research

Policy actors who are members of social groups have social identities and act according to the salient identity

Institutions as rules or venues of decision-making

Institutions might influence group formation and the salience of social identities. Concrete influence is subject to empirics and not to theoretical assumptions

Networks/subsystems

Subsystems and social groups

Ideas or beliefs

Social identities forming shared views of social group members

Context

External factors like political institutions, policy content, external events, public opinion

Events

External events and internal events affecting social groups

important theoretical frameworks of the policy process presenting a first orientation and clarifying its boundaries and opportunities.

The main assumption proposed here is that in the policy subsystem, which presents the usual level of analysis in policy process research, several social identities coexist. In line with the existing research on social identities, these policy-related identities are relevant to the policy process. Drawing from the state of the art in social psychological research presented in section "The social identity approach", one research interest lies in the analysis of which social identities are salient under which policy-related circumstances and in what way they shape individual policy preferences, decision-making and political behavior. Social identities in turn are subject to external and internal forces. External factors acting on the formation, structure, and change of social groups may be 
political institutions, events, public opinion, and the policy content at stake. Likewise, subsystem-internal factors may influence these group-related developments. Among these internal factors are personnel turnovers in the subsystem, scandals or successes of single group members or the group as a whole, the internal group image, and alike. While external and internal factors interact, both in the end shape group-related processes that eventually affect group formation, structures, dynamics, and the salience of social identities. Connecting to the previously elaborated research, we can formulate specific hypotheses for later testing on how social identities play a role in the policy process.

\section{Microlevel of social identities in the policy process}

Based on the assumption that policy actors possess several social identities due to their social identification with multiple social groups, the most general hypotheses from social identity research are transferable to a policy subsystem. Consequently, the strength of a social identity is supposed to be dependent on the degree of social identification (feeling of group belonging, subjective group evaluation, emotional bound) and the degree to which the social identity is internalized, both due to the long history that it persists and due to the frequency of contact to other actors with the same social identity:

Identity Strength Hypotheses: A social identity is stronger...

a. ...the more intense the group belonging.

b. ...the better the (subjective) group evaluation.

c. ...the deeper the emotional bound.

d. ...the longer the identity persists.

e. ...the more frequent the contact to actors sharing the same social identity.

While strength is but one determinant of identity salience, other factors may influence whether and to what extent a specific social identity is salient in a given situation. In the policy process, this especially concerns the arenas of policy-making within which actors find themselves and the policy issue which is subject to discussion and may trigger the salience of an identity. As a result, the concepts of social psychology such as normative and comparative fit as well as accessibility and contextual determinants may be adapted to policy process research as follows:

Identity Salience Hypotheses: Salience of a social identity as determinant for actors' behavior in policy subsystems increases

a. ...with the extent to which this social identity fits the policy issue at hand so that different normative stances on the policy issue are reflected by different social groups (normative fit).

b. ...with the extent to which the actor perceives differences between members of this (his) social group as smaller than in comparison to members of other social groups relevant in the policy subsystem (comparative fit).

c. ...with the strength of this social identity (see identity strength hypotheses) (accessibility).

d. ...with the extent to which the policy issue at hand activates a given social identity (context). 
Staying on a microlevel of analysis and building on the hypotheses on identity salience, specific hypotheses can be derived on policy actors' attitudes and behavior. Specifically, if policy actors possess multiple social identities, which is assumed, the work by Roccas and Brewer (2002) on social identity complexity suggests that the actors' behavior when following the salient social identity is dependent on the structure of these multiple social identifications. Both values and behavior of actors are postulated to be a function of the salient social identity (or salience of multiple identities), as in political science the work of Goren (2005) indicates.

Identity Conflict Hypothesis: Policy actors possess several social identities. In each situation in the policy process, the nature and interrelation of an individual's multiple identities determine the salience of identities and guides the actor's behavior.

Identity Value Hypothesis: Actors in the policy process follow in their values, preferences, and opinions their salient social identity.

Identity Behavior Hypothesis: Actors in the policy process follow in their behavior their salient social identity.

\section{Mesolevel of social identities in the policy process}

In policy process research, the focus of analysis at times shifts from the individual to a collective actor. In such cases, the social identity approach provides insights that allow for depicting group dynamics related to collective identities. Social groups produce shared views on specific policies that demarcate them from other out-groups, whereas the development of a collective identity follows the internal structure of the group and is therefore strongly dependent on the group leadership. Consequently, the social identity approach can provide explanations for collective action, which is among the research interests of policy process research. Following the argument of social identification, collective action between individuals is a function of the commonality of the identities that these individuals exhibit. If their characteristics of their (multiple) identities overlap or if they even share social identities, collective action between them is more likely because the feeling of belonging together to a group will be particularly strong. With respect to collective action between social groups, the role of group leaders is important. As group leaders essentially coin the dynamics, attitudes, and values of social groups, frequent contact between opposing groups' leaders can overcome intergroup differences and lead to collective action between social groups. Such type of collective action is also more likely if there exists a superordinate identity that is stronger than the subordinate identity, as it emphasizes the characteristics that bind the social groups that are to act collectively rather than outlining the features that separate them.

\section{Collective Action Identity Hypotheses:}

a. Collective action among individual policy actors is more likely the greater the degree of their overlapping and shared social identities.

b. Collective action among social groups is more likely the more frequent there is intergroup contact between group leaders.

c. Collective action among social groups is more likely the stronger the group leaders' superordinate identity is compared to the subordinate identity. 


\section{Macrolevel of social identities in the policy process}

Beyond these micro- and mesolevel hypotheses, five types of social identities may be observable on a macrolevel and relevant to the politics of the policy process, each of which is described in detail below, each with reference to empirical evidence from other psychological studies. Briefly worded, social identities may manifest themselves as (1) a local identity, both in terms of geography and political decision levels, (2) a sectoral identity concerning a policy sector or policy expertise committee, (3) an organizational identity, which might be a partisan identity or an interest association identity, but includes also other forms of organizations, from clerical to trade unions or alumni networks, (4) a demographic identity stemming from demographic characteristics, and (5) informal identities, which comprise all sorts of informal social groups such as networks of policy actors, privately organized friend meetings, hobby groups, etc. Obviously, the latter type of identity is the hardest to assess empirically. Studies should therefore start with an evaluation of the other identities and-following the method of sufficient complexity (Lindenberg 2001) —include informal identities and the mesolevel and microlevel only when the former do not provide an encompassing explanation. A macrolevel answers questions of which sort of social identities are relevant for which issues, how political systems and/or venues may address certain social identities and others not. However, the macrolevel will not be able to prove causality and to capture the entire subsystem. To do so, it is necessary to combine the levels of analyses and methods.

\section{Local identity}

Political elites, especially politicians, in their daily communication operate in several political loci. These may be determined by the political level (federal, state, county) (Kolata et al. 2015), by the predominant culture (Gupta and Ferguson 1992), or by the location (north vs. south, east vs. west). For example, Uzzell et al. (2002) found that place-related identity affects attitudes on environmental sustainability - the location of a community and the related social cohesion and local identity influence individual preferences. Especially since the European integration, some people consider themselves rather like a national citizen and some rather like a European. In a similar vein, Kennedy (2012) explores the link between supranational, national, and local identity on the one side and democratic and post-materialist values on the other. Whether the country is federal (like the USA), has a mixed electoral system with direct and list mandates (like Germany) or a cleavage between larger cities and counties (like Switzerland)-examples of local identities are manifold. Consequently, the assumption immediately suggests that local identities shape the view on specific policies. Looking up to escalation research, the NIMBY (Not In My Backyard; (Di Nucci and Brunnengräber 2017) debates often circle around where people live and how they will be affected-and compensated-for negative consequences of large infrastructure projects. A politician may regard one local identity as more important than another, or may be more aware of the one that is more closely connected to a policy at stake. This may be dependent on their electoral mandate (Olivella and Tavits 2013) or local concerns (Bonaiuto et al. 2002). Additionally, the effect of other identities on policy preferences may be moderated by a local community (Deleon and Naff 2016). 


\section{Sectoral identity}

While every person has some kind of local identity, the second category of identities introduced here might only be central for policy elites. In any modern political system, there is a need for specialization which forces political elites to join one or more sectors. Scholars have found an intergroup-related policy conflict between a welfare state elite (called "custodians" of the health sector) and a fiscal elite (called "austerians" and mainly comprising the ministry of finances), in French health policy (Genieys 2010; Hassenteufel et al. 2010). These are types of sectoral identities that may shape policy processes. In light of SIPP, the sectoral identity shapes a common view on certain policies. An empirical example is presented by Drulák et al. (2003), who observe that Czech civil servants in the EU act rather in line with their sectoral affiliation-thus cooperating with actors from the same sectoral affiliation-instead of their national identity. When different sectors participate in policy-making, social identities ascribed to each of the sector may coin different preferences: Air pollution control is perceived differently among individual politicians depending on whether they are an environmental or an economic politician. Another example is genetic engineering, negotiated within different sectors, like research policy, health policy, environmental policy and economic policy (Bandelow 2006). Some sectoral identities may be stronger than others, such as the military sector may be particularly strong in coining social identity (Hislop 2002). When sectoral identities change, e.g., when politicians or civil servants change sectoral affiliations, these changes can explain changes in individual preferences if the change of sector leads to new group memberships of individuals. Sectoral identity is expressed through intensive occupation within a policy sector, e.g., through work in a ministry or membership in parliamentary expert committees.

\section{Organizational identity}

Organizational membership forms the third expression of social identity discussed here (Hogg and Terry 2000; Ashforth and Schinoff 2016). Policy actors are often members of political parties or interest groups. Partisanship influences MPs' behavior in a number of ways. Firstly, parliamentary parties are to various extents hierarchically structured and impose the obligation to vote in accordance with party policy on individuals (André et al. 2013; Detterbeck 2011). Such cases are only of limited suitability to picture predominance of identities. Although not all political decisions succumb this obligation, the identification with a party predicts behavior better than an associated ideology (Bankert et al. 2016), which presents partisanship as a social group membership that is particularly relevant in policy processes, because parties essentially shape values regarding specific topics, particularly those that recently emerged (Vogeler 2018). Partisanship is generally considered to be a stronger social identity with individual loyalty being high (Clifford 2017). However, other organizational identities, such as the membership in interest associations (Nadler and Hannon 2013) and trade unions (Cregan et al. 2009), but also the religious identity as a member of a church (Różycka-Tran 2017) have shown to be relevant social identities.

\section{Demographic/biographic identity}

While the research on legislative behavior in parliamentary systems still focuses on the role of parties, there is a rising bulk of literature that also acknowledges characteristics of individual MPs, especially sociodemographic properties, as influential on voting behavior 
(Baumann et al. 2015). A specificity of demographic and biographic identities is that they are almost unchangeable. It is not (in a natural way) possible to change age or sex. It is not possible to undo an education once obtained, or to not have the children already born. All these characteristics may affect a demographic identity and depending on a policy issue this may become salient. Therefore, it may be sometimes possible that a shared demographic identity translates into shared policy preferences. This may be a definable social group that corroborates its views through communication as an underrepresented group (Mehra et al. 1998) or merely a shared demographic characteristic, such as gender, that shapes a specific political ideology (Deleon and Naff 2016). Demographic identities also comprise elements of an individual biography, such as professional identity (Thorne 2017) or university attendance (Stubager 2009).

\section{Informal identities}

Organizational research early outlined the specific importance of formal and informal groups in organizations, which expedite group formation and social identification (Ashforth and Mael 1989). Discussions about politics often take place in informal groups, with a high potential of polarization and social division (Walsh 2004). Informal groups present a type of organization, but the difference compared to the organizational identity is that the individual membership in this group is often not visible. Likewise, informal groups can take all sorts of forms, such as a pub quiz team (Jenkins 2014), or, with regard to the ACF, an advocacy coalition identity, as advocacy coalitions are a type of informal social group with a specific group identification. They can also depict social groups that evolved through biographical intersections and surpassed sectoral identities to form a programmatic group (Hornung and Bandelow 2018). The possible variety of informal groups makes them even harder to identify when not knowing what to look for. Nevertheless, informal groups often exert much more influence than formal groups and provide more room for unexpected maneuver.

\section{Integrating SIPP: past and future research}

The previous sections have shown that an integration of the social identity approach into policy process research is particularly fruitful and provides the potential to gain new insights into individual and collective actors' behavior and preferences in policy-making and decision-making processes. Whereas the elaborated considerations are grounded in the positive sense of identification with a group and the respective consequences for individual, intra- and intergroup characteristics, an expanded model of identification might equally prove useful in the study of policy processes. Kreiner and Ashforth (2004) further developed organizational identification by examining disidentification, ambivalent identification, and neutral identification. Disidentification means that an individual does not identify with aspects of an organization (or any other group). Identification and disidentification are not two ends of a bipolar scale but in fact two separate concepts of striving toward a positive identity. Simultaneously identifying and disidentifying with aspects of a social group results in ambivalent identification. Owed to the increased complexity of social groups, norms, values, and practices, an individual's social identification thus might stem from positive identification (in the sense that it identifies with aspects of a social group), from negative identification (in the sense that it disidentifies with aspects of a social group), 
from ambivalent identification where different or the same aspects of a social group at once foster identification and disidentification, or neither form of social identification. The latter is termed neutral identification, whereas neutral identification can be self-identifying, too, in the sense that an individual does not involve in extreme conflict or take sides in a dispute. Evidence has shown that these dimensions of identification correlate with the individual's organizational citizenship behavior (Schuh et al. 2016). Transferring these findings to politics, ambivalent identification may yield to what extent policy actors of social groups behave with the aim of contributing to better group performance (e.g., in political communication) and to outputs that are beneficial to the group (e.g., in view of policy decisions that affect social groups in the subsystem). The hypotheses merely would have to be adjusted accordingly to control for these types of identification.

While SIPP may be applied as a sole theoretical perspective in studies of the policy process, it may equally serve as addendum to established theoretical frameworks to enhance the analysis of individual preference formation and behavior. The widely established multiple streams framework (MSF) (Herweg et al. 2017) predicates its model of the individual on bounded rationality in the form of cognitive limitations and ambiguity (Zahariadis 2003). Ambiguity refers to an unclearly definable problem definition—as a problem definition is always vague and potential solutions are various-and resulting unclear policy preferences of policy actors. Social identities may tie in at this point and shed light on the preference formation of policy actors that emerges in interaction with others (intergroup relations) or concretize the concept of ambiguity through the connection with ambivalent social identification. Similarly, psychological research has used social identities to explain actors' behavior in reducing uncertainty (Hogg 2011). This might equally inform MSF research as a new lens through which to explain decision-making under situations of uncertainty. Linking to the idea of ambiguous problem definitions and actors' preferences, the MSF posits that three independent streams of problem definitions, policy solutions, and political circumstances flow next to each other and that to effect policy change, a policy entrepreneur must couple these streams when time is right (defined through the opening of a window of opportunity) and put a given solution to a given problem on the political agenda (Zohlnhöfer et al. 2015). In the view of SIPP, actors would have ambiguous preferences only until a social identity is activated - although this does not contradict ambiguity. Still, ambivalent social identification can go along with ambiguous actors' preferences. An important factor to observe for policy entrepreneurs to couple streams would be to exclude triggers of social identities of others that would contradict his policy solution or, in positive terms, to make salient a latent identity of a relevant actor salient.

As a second major theoretical framework, the advocacy coalition framework (ACF) (Jenkins-Smith et al. 2017) is suitable for providing an anchor for the integration of SIPP into policy process research. The ACF assumes that actors possess a triad of beliefs, including deep normative core beliefs that are consolidated in early childhood and hardly changeable, policy core beliefs that are stable over around a decade and present the binding element of advocacy coalitions in a subsystem, and secondary aspects that are adaptable in favor of the more fundamental beliefs (Leach and Sabatier 2005). One can argue, however, that advocacy coalitions present a type of social group, which is also reflected by biased perception of maliciousness and power of in-group and out-group members-a phenomenon that the ACF labels devil shift (Sabatier et al. 1987; Vogeler and Bandelow 2018). Among the parallels of the ACF and SIPP are the assumptions that policy is formulated in the subsystem, that political institutions present opportunity structures within which actors move, and that external subsystem events may affect resources and constraints of actors (Jenkins-Smith et al. 2017). As a result, the focus on social identities may reveal 
why subsystem actors possess certain resources and others not because these may be connected with belonging to a social group. Social identities may explain both stability and change in the policy process, when considering that strong social groups persist over time while other, weaker social groups might diminish and be replaced by new ones. Social identities also can be considered as the basis of individual belief and preference formation, which probably presents the most interesting contribution to the ACF research on coalition formation and connects to recent research on coalition building (Sotirov and Winkel 2016). When social identities overlap and thus beliefs are more similar, coalition formation becomes more likely. One type of social identity could also be an advocacy coalition identity, which then coins beliefs instead of being the result of shared beliefs. Advocacy coalitions might then be the result of other pre-existing social identities. Thereby, SIPP adds to the explanation of collective action, as scholars advised to draw on other frameworks to shed light on this specific element (Schlager 1995).

Whose social identities should we analyze? As our aim is to explore the dynamics in the policy process, the social identities that matter are the ones within the policy subsystem. Subsystems in this understanding involve all actors that have a relevant influence on a policy, independent of whether this competence results from a formal position in the political system or from factual power resulting from a key position in a network or interest association. Therefore, chairmen of political parties or interest associations might be considered as members of the policy subsystems even if they are not possessing formal decision power. The five identities established on the macroperspective thereby can each potentially apply to all members of a policy subsystem.

How should we analyze social identities? Concerning the three levels of analysis, an investigation on all three levels is as possible as focusing only on one of them. The microlevel concerns the very heart of psychological research, namely why people identify with groups and how their social identities affect individual thinking and behavior. On a mesolevel, research on internal group dynamics and intergroup attitudes and relations may take place. Both of these levels normally require interviews or qualitative analyses of documents and group-concerned information. More easily, studies may assess the shared characteristics of policy actors on a macrolevel to approach individual social identities. Thus, what we propose to follow in the research agenda is at first the principle of sufficient complexity, which proposes to conduct analyses at first on the least complex level and to proceed with more in-depth research if necessary. Hence, the suggestion is to depict social identities on a macrolevel by looking at variables that actors may share and use them as indicators of social identities.

To give a methodological example, voting behavior in roll-call votes that are freed from the obligation to vote in accordance with party policy may reveal salient identities when looking at the shared characteristics (such as other organizational bonds, direct or list mandates as local identities, committee membership as a sectoral identity or demographic characteristics like gender, age, etc., to name but a few examples) (Engler and Dümig 2017). With regard to actors' behavior, this strategy enables us to identify shared identities and to assess which identity was decisive for a specific vote or preference due to the underlying coordinated action. In-depth research on the individual level then would only be necessary when identities visible on the surface do not appropriately explain the dynamics. Indeed, rarely will we be able to fully capture the policy process by analyzing the macrolevel. However, this allows us large-scale international comparisons and datasets whose analyses may be generalized widely before proceeding with in-depth studies on group dynamics and individual social identities. Despite not exactly conceiving the individual social identities, this method approaches them with a well-funded theoretical argument through 
characteristics that are believed to be closely linked to group identities. When capturing social identities on the most visible level does not yield explanations for specific observations, the method to choose to assess which individual's identification with a social group has driven his or her actions, SIPP leaves the possibility to research in-depth by using questionnaires or through interviews on a qualitative level.

SIPP builds the ground for a larger research agenda. Besides its potential to cover an important and complementary place when being combined with existing frameworks, the micro-, meso-, and macrolevel mapped in the previous sections may stand alone as a new theoretical lens in policy process research. An application of this perspective must account for the fact that the five types of identity are not cut in stone. Other identity types may be more relevant for other policies. A combination of identities may be equally important for one policy as just one not yet described identity for another. It is up to each researcher to theoretically derive the identities that may be pertinent to the subject under study and to empirically assess which one dominates for preference formation and behavior.

\section{Conclusion}

This paper introduces SIPP as a new theoretical lens for the analysis of policy processes. It draws on the widely acknowledged psychological social identity approach informed by SIT and SCT to formulate new hypotheses on the dynamics in policy subsystems as well as within and between coalitions. Upon condition that an individual identifies with a social group, this process leads to the formation of a social identity. The main idea of SIPP is to use this concept of social identities to explain policy actors' behavior and attitudes in policy processes and eventually to shed light on the underlying dynamics of policy-making and decision-making.

The second and third section of this contribution formulate corresponding hypotheses on the micro- and mesolevel and identify five social identities on the macrolevel that are potentially relevant to policy processes. On the microlevel, the salience of social identities of individual policy actors in given political situations is of main interest. The mesolevel especially regards a collective identity shaped by leaders of social groups and corresponding intra- and intergroup relations. Lastly, the macrolevel provides an opportunity for researchers to understand coordinated action on the basis of shared social identities visible on the surface. Depending on which social identity is salient in a given situation in the policy process, actors' preferences and behavior align with this identity. Assessing these allows the researcher to explain conflict and cooperation between policy actors, policy actors' preferences, behavior, and decisions, as well as policy outcomes.

Methodologically, SIPP offers a wide array of future research opportunities. Starting from the macrolevel in line with the principle of sufficient complexity, large-scale quantitative data on decision-making process can inform research in the way that characteristics of individual actors participating in these processes can be compared and point at potentially underlying social identities. Thus, specific outcomes can be explained without researching in-depth but merely when looking at the obvious social groups between which line of conflict evolved, when regarding the arguments put forward by each individual that hint arguments of a social group, or when collating final votes that seem to be portrayals of the social groups involved. Only when this level of analysis does not yield satisfying insights, it is through questionnaires and qualitative research that researchers can approximate the individuals and the driving identity-related aspects that guide their actions. Since 
psychological research has paved much of the way up to this integration of the social identity approach into policy process research, there exists an extensive pool of methods and methodological approaches that is yet to be discovered by political scientists.

Building on the introduction of SIPP on a micro-, meso-, and macrolevel, a new research agenda opens beyond the presented possibilities. Thereby, the theoretical lens of SIPP does not need to stand alone-even though it can—but also provides the possibility of being combined with other theoretical frameworks. It might be applied in different contexts, and with regard to different policies. Moreover, scholars may concentrate on only one element of SIPP in their analysis, or use it on only one level of analysis. SIPP enhances the understanding of policy-making, independent of political systems and cultures, institutions and external circumstances, or subsystem-internal developments, although these may in turn have an impact on the formation of social identities. But it is through social identities, this paper argues, that actors orientate themselves in the political world and find an anchor that guides them through it.

Funding Funding was provided by Deutsche Forschungsgemeinschaft (Grant No. BA 1912/3-1) and Agence Nationale de la Recherche (Grant No. ANR-17-FRAL-0008-01).

Open Access This article is distributed under the terms of the Creative Commons Attribution 4.0 International License (http://creativecommons.org/licenses/by/4.0/), which permits unrestricted use, distribution, and reproduction in any medium, provided you give appropriate credit to the original author(s) and the source, provide a link to the Creative Commons license, and indicate if changes were made.

\section{References}

Adams, B. G., \& van de Vijver, F. J. R. (2015). The many faces of expatriate identity. International Journal of Intercultural Relations, 49, Supplement C, 322-331. https://doi.org/10.1016/j.ijintrel.2015.05.009.

André, A., Depauw, S., \& Beyens, S. (2013). Party loyalty and electoral dealignment. Party Politics, 21(6), 970-981. https://doi.org/10.1177/1354068813509521.

Ashforth, B. E., \& Mael, F. (1989). Social identity theory and the organization. Academy of Management Review, 14(1), 20-39.

Ashforth, B. E., \& Schinoff, B. S. (2016). Identity under construction: How individuals come to define themselves in organizations. Annual Review of Organizational Psychology and Organizational Behavior, 3(1), 111-137. https://doi.org/10.1146/annurev-orgpsych-041015-062322.

Bandelow, N. C. (2006). Advocacy coalitions, policy-oriented learning and long-term change in genetic engineering policy: An interpretist view. German Policy Studies, 3(4), 743-795.

Bandelow, N. C., Vogeler, C. S., Hornung, J., Kuhlmann, J., \& Heidrich, S. (2017). Learning as a necessary but not sufficient condition for major health policy change: A qualitative comparative analysis combining ACF and MSF. Journal of Comparative Policy Analysis: Research and Practice. https://doi. org/10.1080/13876988.2017.1393920.

Bankert, A., Huddy, L., \& Rosema, M. (2016). Measuring partisanship as a social identity in multi-party systems. Political Behavior, 39(1), 103-132. https://doi.org/10.1007/s11109-016-9349-5.

Bartle, J., \& Bellucci, P. (2009). Political parties and partisanship: social identity and individual attitudes (Routledge/ECPR studies in European political science, Vol. 57). London: Routledge.

Baumann, M., Debus, M., \& Müller, J. (2015). Personal characteristics of MPs and legislative behavior in moral policymaking. Legislative Studies Quarterly, 40(2), 179-210. https://doi.org/10.1111/1sq.12072

Béland, D. (2017). Identity, politics, and public policy. Critical Policy Studies, 11(1), 1-18. https://doi. org/10.1080/19460171.2016.1159140.

Bonaiuto, M., Carrus, G., Martorella, H., \& Bonnes, M. (2002). Local identity processes and environmental attitudes in land use changes: The case of natural protected areas. Journal of Economic Psychology, 23(5), 631-653. https://doi.org/10.1016/S0167-4870(02)00121-6.

Bonneau, C. W., \& Cann, D. M. (2013). Party identification and vote choice in partisan and nonpartisan elections. Political Behavior, 37(1), 43-66. https://doi.org/10.1007/s11109-013-9260-2. 
Boydstun, A. E., \& Glazier, R. A. (2013). A two-tiered method for identifying trends in media framing of policy issues: The case of the war on terror. Policy Studies Journal, 41(4), 706-735. https://doi. org/10.1111/psj.12038.

Brewer, M. B. (1991). The social self: On being the same and different at the same time. Personality and Social Psychology Bulletin, 17(5), 475-482. https://doi.org/10.1177/0146167291175001.

Cairney, P., \& Weible, C. M. (2017). The new policy sciences: Combining the cognitive science of choice, multiple theories of context, and basic and applied analysis. Policy Sciences, 50(4), 619-627. https:// doi.org/10.1007/s11077-017-9304-2.

Campbell, A., Converse, P. E., Miller, W. E., \& Stokes, D. E. (1960). The American voter. Chicago: University of Chicago Press.

Clifford, S. (2017). Individual differences in group loyalty predict partisan strength. Political Behavior, 39(3), 531-552. https://doi.org/10.1007/s11109-016-9367-3.

Cole, M. S., \& Bruch, H. (2006). Organizational identity strength, identification, and commitment and their relationships to turnover intention: Does organizational hierarchy matter? Journal of Organizational Behavior, 27(5), 585-605. https://doi.org/10.1002/job.378.

Cregan, C., Bartram, T., \& Stanton, P. (2009). Union organizing as a mobilizing strategy: The impact of social identity and transformational leadership on the collectivism of union members. British Journal of Industrial Relations, 47(4), 701-722. https://doi.org/10.1111/j.1467-8543.2009.00733.x.

Dancey, L., \& Goren, P. (2010). Party identification, issue attitudes, and the dynamics of political debate. American Journal of Political Science, 54(3), 686-699.

Deleon, R. E., \& Naff, K. C. (2016). Identity politics and local political culture. Urban Affairs Review, 39(6), 689-719. https://doi.org/10.1177/1078087404264215.

Detterbeck, K. (2011). Party careers in federal systems. Vertical linkages within Austrian, German, Canadian and Australian Parties. Regional \& Federal Studies, 21(2), 245-270. https://doi.org/10.1080/13597 566.2011.530021.

Di Nucci, M. R., \& Brunnengräber, A. (2017). In whose backyard? The wicked problem of siting nuclear waste repositories. European Policy Analysis, 3(2), 295-323. https://doi.org/10.1002/epa2.1028.

Drulák, P., Cesal, J., \& Hampl, S. (2003). Interactions and identities of Czech civil servants on their way to the EU. Journal of European Public Policy, 10(4), 637-654. https://doi.org/10.1080/1350176032 000101299.

Ellemers, N., De Gilder, D., \& Haslam, S. A. (2004). Motivating individuals and groups at work: A social identity perspective on leadership and group performance. The Academy of Management Review, 29(3), 459-478. https://doi.org/10.2307/20159054.

Ellemers, N., Kortekaas, P., \& Ouwerkerk, J. W. (1999). Self-categorisation, commitment to the group and group self-esteem as related but distinct aspects of social identity. European Journal of Social Psychology, 29, 371-389.

Engler, F., \& Dümig, K. (2017). Political parties and MPs' morality policy voting behaviour: Evidence from Germany. Parliamentary Affairs, 70(3), 548-568. https://doi.org/10.1093/pa/gsw034.

Epitropaki, O., Kark, R., Mainemelis, C., \& Lord, R. G. (2017). Leadership and followership identity processes: A multilevel review. The Leadership Quarterly, 28(1), 104-129. https://doi.org/10.1016/j. leaqua.2016.10.003.

Fielding, K. S., \& Hornsey, M. J. (2016). A social identity analysis of climate change and environmental attitudes and behaviors: Insights and opportunities. Frontiers in Psychology, 7, 121. https://doi. org/10.3389/fpsyg.2016.00121.

Genieys, W. (2010). The new custodians of the state: Programmatic elites in french society. New Brunswick, NJ: Transaction Publishers.

Gilad, S., \& Alon-Barkat, S. (2017). Enhancing democracy via bureaucracy: Senior managers' social identities and motivation for policy change. Governance, 31(2), 359-380. https://doi.org/10.1111/ gove. 12300 .

Goren, P. (2005). Party identification and core political values. American Journal of Political Science, 49(4), 881-896.

Greene, S. (1999). Understanding party identification: A social identity approach. Political Psychology, 20(2), 393-403. https://doi.org/10.1111/0162-895X.00150.

Greene, S. (2004). Social identity theory and party identification*. Social Science Quarterly, 85(1), 136153. https://doi.org/10.1111/j.0038-4941.2004.08501010.x.

Grohs, R., Reisinger, H., \& Woisetschläger, D. M. (2015). Attenuation of negative sponsorship effects in the context of rival sports teams' fans. European Journal of Marketing, 49(11/12), 1880-1901. https:// doi.org/10.1108/EJM-01-2013-0010.

Gupta, A., \& Ferguson, J. (1992). Beyond "culture": Space, identity, and the politics of difference. Cultural Anthropology, 7(1), 6-23. 
Haslam, C., Jetten, J., Haslam, S. A., Pugliese, C., \& Tonks, J. (2011a). 'I remember therefore I am, and I am therefore I remember': Exploring the contributions of episodic and semantic self-knowledge to strength of identity. British Journal of Psychology, 102(2), 184-203. https://doi.org/10.1348/00071 $2610 \times 508091$.

Haslam, S. A. (2001). Psychology in organizations: The social identity approach. Thousand Oaks: SAGE.

Haslam, S. A. (2014). Making good theory practical: Five lessons for an applied social identity approach to challenges of organizational, health, and clinical psychology. British Journal of Social Psychology, 53(1), 1-20. https://doi.org/10.1111/bjso.12061.

Haslam, S. A., Eggins, R. A., \& Reynolds, K. J. (2003). The ASPIRe model: Actualizing social and personal identity resources to enhance organizational outcomes. Journal of Occupational and Organizational Psychology, 76(1), 83-113. https://doi.org/10.1348/096317903321208907.

Haslam, S. A., Oakes, P. J., Reynolds, K. J., \& Turner, J. C. (1999). Social identity salience and the emergence of stereotype consensus. Personality and Social Psychology Bulletin, 25(7), 809-818. https:// doi.org/10.1177/0146167299025007004.

Haslam, S. A., Reicher, S., \& Platow, M. (2011b). The new psychology of leadership: Identity, influence, and power. Hove, East Sussex; New York: Psychology Press.

Hassenteufel, P., Smyrl, M., Genieys, W., \& Moreno-Fuentes, F. J. (2010). Programmatic actors and the transformation of european health care states. Journal of Health Politics, Policy and Law, 35(4), 517538. https://doi.org/10.1215/03616878-2010-015.

Heikkila, T., \& Cairney, P. (2017). Comparison of theories of the policy process. In C. M. Weible \& P. A. Sabatier (Eds.), Theories of the policy process (4th ed., pp. 301-326). Boulder, CO: Westview Press.

Herweg, N., Zahariadis, N., \& Zohlnhöfer, R. (2017). The multiple streams framework: Foundations, refinements, and empirical applications. In C. M. Weible \& P. A. Sabatier (Eds.), Theories of the policy process (4th ed., pp. 17-53). Boulder, CO: Westview Press.

Hirsh, J. B., \& Kang, S. K. (2015). Mechanisms of identity conflict: Uncertainty, anxiety, and the behavioral inhibition system. Personality and Social Psychology Review, 20(3), 223-244. https://doi. org/10.1177/1088868315589475.

Hislop, D. (2002). Environmental constraints and sectoral recipes: Strategy change in Britain's military industrial base. Journal of Management Studies, 37(5), 687-703. https://doi.org/10.1111/14676486.00199.

Hogg, M. A. (2011). Subjective uncertainty reduction through self-categorization: A motivational theory of social identity processes. European Review of Social Psychology, 11(1), 223-255. https://doi. org/10.1080/14792772043000040.

Hogg, M. A., Abrams, D., \& Brewer, M. B. (2017). Social identity: The role of self in group processes and intergroup relations. Group Processes \& Intergroup Relations, 20(5), 570-581. https://doi. org/10.1177/1368430217690909.

Hogg, M. A., Abrams, D., Otten, S., \& Hinkle, S. (2004). The social identity perspective: Intergroup relations, self-conception, and small groups. Small Group Research, 35(3), 246-276. https://doi. org/10.1177/1046496404263424.

Hogg, M. A., \& Terry, D. J. (2000). Social identity and self-categorization processes in organizational contexts. The Academy of Management Review, 25(1), 121-140.

Hornsey, M. J. (2008). Social identity theory and self-categorization theory: A historical review. Social and Personality Psychology Compass, 2(1), 204-222. https://doi.org/10.1111/j.1751-9004.2007.00066.x.

Hornung, J., \& Bandelow, N. C. (2018). The programmatic elite in German health policy: Collective action and sectoral history. Public Policy and Administration. https://doi.org/10.1177/0952076718798887.

Huddy, L. (2001). From social to political identity: A critical examination of social identity theory. Political Psychology, 22(1), 127-156. https://doi.org/10.1111/0162-895X.00230.

Jenkins, R. (2014). Social identity (Fourth Edition. ed., Key Ideas). New York: Routledge

Jenkins-Smith, H. C., Nohrstedt, D., Weible, C. M., \& Ingold, K. (2017). The advocacy coalition framework: An overview of the research program. In C. M. Weible \& P. A. Sabatier (Eds.), Theories of the policy process (pp. 135-170). Boulder, CO: Westview Press.

Kakachia, K., \& Minesashvili, S. (2015). Identity politics: Exploring Georgian foreign policy behavior. Journal of Eurasian Studies, 6(2), 171-180. https://doi.org/10.1016/j.euras.2015.04.002.

Kennedy, R. (2012). The role of supranational identity in promoting democratic values. European Union Politics, 14(2), 228-249. https://doi.org/10.1177/1465116512466604.

Kim, H. (2017). The indirect effect of political identity salience on voting intention through in-group-outgroup difference in the perceived influence of polling reports. International Journal of Public Opinion Research. https://doi.org/10.1093/ijpor/edx011.

Klandermans, P. G. (2014). Identity politics and politicized identities: Identity processes and the dynamics of protest. Political Psychology, 35(1), 1-22. https://doi.org/10.1111/pops.12167. 
Kolata, A. L., Charnoz, O., \& Diaz Pedregal, V. (Eds.). (2015). Local politics, global impacts: Steps to a multi-disciplinary analysis of scales (Global governance). Farnham, Surrey: Ashgate.

Kreiner, G. E., \& Ashforth, B. E. (2004). Evidence toward an expanded model of organizational identification. Journal of Organizational Behavior, 25(1), 1-27. https://doi.org/10.1002/job.234.

Lasswell, H. D. (1970). The emerging conception of the policy sciences. Policy Sciences, 1(1970), 3-14. https://doi.org/10.1017/S0003055400302453.

Leach, W. D., \& Sabatier, P. A. (2005). To trust an adversary: Integrating rational and psychological models of collaborative policymaking. American Political Science Review, 99(4), 491-503. https://doi. org/10.1017/S000305540505183X.

Leonardelli, G. J., Pickett, C. L., \& Brewer, M. B. (2010). Chapter 2-Optimal distinctiveness theory: A framework for social identity, social cognition, and intergroup relations. In M. P. Zanna \& J. M. Olson (Eds.), Advances in experimental social psychology (Vol. 43, pp. 63-113). New York: Academic Press.

Light, R. (2015). Like strangers we trust: Identity and generic affiliation networks. Social Science Research, 51(Supplement C), 132-144. https://doi.org/10.1016/j.ssresearch.2014.12.016.

Lindenberg, S. (2001). Social rationality versus rational egoism. In J. H. Turner (Ed.), Handbook of sociological theory (pp. 635-668). New York: Kluwer Academic.

Lipset, S. M., \& Rokkan, S. (1967). Cleavage structures, party systems, and voter alignment: An introduction. In S. M. Lipset \& S. Rokkan (Eds.), Party systems and voter alignments: Cross-national perspectives (pp. 1-64). New York: Collier-Macmillan.

Liu, J. H., \& Hilton, D. J. (2005). How the past weighs on the present: Social representations of history and their role in identity politics. British Journal of Social Psychology, 44(4), 537-556. https://doi. org/10.1348/014466605X27162.

Mavor, K. I., Platow, M. J., \& Bizumic, B. (2017). Self and social identity in educational contexts. New York: Routledge.

Mehra, A., Kilduff, M., \& Brass, D. J. (1998). At the Margins: A distinctiveness approach to the social identity and social networks of underrepresented groups. Academy of Management Journal, 41(4), 441-452. https://doi.org/10.5465/257083.

Miles, M. R. (2016). Presidential appeals to Moral foundations: How modern presidents persuade crossideologues. Policy Studies Journal, 44(4), 471-490. https://doi.org/10.1111/psj.12151.

Miller, W. E. (1986). Party Identification and political belief systems: Changes in partisanship in the United States, 1980-84. Electoral Studies, 5(2), 101-121. https://doi.org/10.1016/0261-3794(86)90001-6.

Nadler, J. T., \& Hannon, G. Y. (2013). Self-selected social identification measure (SSIM): A survey assessing identity based on group membership. North American Journal of Psychology, 15(3), 425-446.

Naples, N. A., \& Bickham Mendez, J. (Eds.). (2015). Border politics: Social movements, collective identities, and globalization. New York: NYU Press.

Nohrstedt, D., \& Olofsson, K. (2016). A review of applications of the advocacy coalition framework in Swedish policy processes. European Policy Analysis, 2(2), 18-42. https://doi.org/10.18278/epa.2.2.3.

Oakes, P. J., Turner, J. C., \& Haslam, S. A. (1991). Perceiving people as group members: The role of fit in the salience of social categorizations. British Journal of Social Psychology, 30(2), 125-144. https:// doi.org/10.1111/j.2044-8309.1991.tb00930.x.

Olivella, S., \& Tavits, M. (2013). Legislative effects of electoral mandates. British Journal of Political Science, 44(02), 301-321. https://doi.org/10.1017/s0007123412000828.

Parsons, B. M. (2015). The social identity politics of peer networks. American Politics Research, 43(4), 680-707. https://doi.org/10.1177/1532673x14546856.

Peters, K., Haslam, S. A., Ryan, M. K., \& Fonseca, M. (2013). Working with subgroup identities to build organizational identification and support for organizational strategy: A test of the ASPIRe model. Group and Organization Management, 38(1), 128-144. https://doi.org/10.1177/1059601112472368.

Polletta, F., \& Jasper, J. M. (2001). Collective identity and social movements. Annual Review of Sociology, 27, 283-305.

Posner, D. N. (2017). When and why do some social cleavages become politically salient rather than others? Ethnic and Racial Studies, 40(12), 2001-2019. https://doi.org/10.1080/01419870.2017.1277033.

Reynolds, K. J., Lee, E., Turner, I., Bromhead, D., \& Subasic, E. (2017). How does school climate impact academic achievement? An examination of social identity processes. School Psychology International, 38(1), 78-97. https://doi.org/10.1177/0143034316682295.

Richter, A. W., West, M. A., van Dick, R., \& Dawson, J. F. (2006). Boundary Spanners' identification, intergroup contact, and effective intergroup relations. Academy of Management Journal, 49(6), 12521269. https://doi.org/10.5465/amj.2006.23478720.

Roccas, S., \& Brewer, M. B. (2002). Social identity complexity. Personality and Social Psychology Review, 6(2), 88-106. https://doi.org/10.1207/S15327957PSPR0602_01. 
Różycka-Tran, J. (2017). Love thy neighbor? The effects of religious in/out-group identity on social behavior. Personality and Individual Differences, 115(Supplement C), 7-12. https://doi.org/10.1016/j. paid.2016.11.009.

Sabatier, P. A. (1999). Theories of the policy process (Theoretical lenses on public policy). Boulder, CO: Westview Press.

Sabatier, P. A. (2007). Theories of the policy process (2nd ed.). Boulder, CO: Westview Press.

Sabatier, P. A., Hunter, S., \& McLaughlin, S. (1987). The Devil shift: Perceptions and misperceptions of opponents. The Western Political Quarterly, 40(3), 449-476. https://doi.org/10.2307/448385.

Sabatier, P. A., \& Jenkins-Smith, H. C. (1999). The advocacy coalition framework: An assessment. In P. A. Sabatier (Ed.), Theories of the policy process (Theoretical lenses on public policy). Boulder, CO: Westview Press.

Sabatier, P. A., \& Weible, C. M. (2014). Theories of the policy process (3rd ed.). Boulder, CO: Westview Press.

Schlager, E. (1995). Policy making and collective action: Defining coalitions within the advocacy coalition framework. Policy Sciences, 28(3), 243-270. https://doi.org/10.1007/BF01000289.

Schlager, E., \& Weible, C. M. (2013). New theories of the policy process. Policy Studies Journal, 41(3), 389-396. https://doi.org/10.1111/psj.12030.

Schuh, S. C., Van Quaquebeke, N., Göritz, A. S., Xin, K. R., De Cremer, D., \& van Dick, R. (2016). Mixed feelings, mixed blessing? How ambivalence in organizational identification relates to employees' regulatory focus and citizenship behaviors. Human Relations, 69(12), 2224-2249. https://doi.org/10.1177/0018726716639117.

Sherif, M. (1966). In Common predicament: Social psychology of intergroup conflict and cooperation (The international series in the behavioral sciences). Boston: Houghton Mifflin.

Sides, J., \& Citrin, J. (2007). European opinion about immigration: The role of identities, interests and information. British Journal of Political Science, 37(3), 477-504. https://doi.org/10.1017/S0007 123407000257.

Simon, B., \& Klandermans, B. (2001). Politicized collective identity: A social psychological analysis. American Psychologist, 56(4), 319-331. https://doi.org/10.1037//0003-066X.56.4.319.

Sotirov, M., \& Winkel, G. (2016). Toward a cognitive theory of shifting coalitions and policy change: Linking the advocacy coalition framework and cultural theory. Policy Sciences, 49(2), 125-154. https://doi.org/10.1007/s11077-015-9235-8.

Steffens, N. K., Haslam, S. A., Reicher, S. D., Platow, M. J., Fransen, K., Yang, J., et al. (2014). Leadership as social identity management: Introducing the identity leadership inventory (ILI) to assess and validate a four-dimensional model. The Leadership Quarterly, 25(5), 1001-1024. https://doi. org/10.1016/j.leaqua.2014.05.002.

Stubager, R. (2009). Education-based group identity and consciousness in the authoritarian-libertarian value conflict. European Journal of Political Research, 48(2), 204-233. https://doi.org/10.111 1/j.1475-6765.2008.00834.x.

Subašić, E., Reynolds, K. J., \& Turner, J. C. (2008). The political solidarity model of social change: Dynamics of self-categorization in intergroup power relations. Personality and Social Psychology Review, 12(4), 330-352. https://doi.org/10.1177/1088868308323223.

Suhay, E. (2015). Explaining group influence: The role of identity and emotion in political conformity and polarization. Political Behavior, 37(1), 221-251. https://doi.org/10.1007/s11109-014-9269-1.

Tajfel, H. (1974). Social identity and intergroup behaviour. Information (International Social science council), 13(2), 65-93. https://doi.org/10.1177/053901847401300204.

Tajfel, H. (Ed.). (1982a). Social identity and intergroup relations (European studies in social psychology). Cambridge: Cambridge University Press.

Tajfel, H. (1982b). Social psychology of intergroup relations. Annual Review of Psychology, 33(1), 1-39. https://doi.org/10.1146/annurev.ps.33.020182.000245.

Thomas, E. F., McGarty, C., \& Mavor, K. I. (2009). Aligning identities, emotions, and beliefs to create commitment to sustainable social and political action. Personality and Social Psychology Review, 13(3), 194-218. https://doi.org/10.1177/1088868309341563.

Thorne, L. (2017). Discussion of "A theoretical framework of professional accountants' identity formation and directions for future research". Journal of Business Ethics, 142(2), 239-240. https://doi. org/10.1007/s10551-016-3145-3.

Transue, J. E. (2007). Identity salience, identity acceptance, and racial policy attitudes: American national identity as a uniting force. American Journal of Political Science, 51(1), 78-91. https:// doi.org/10.1111/j.1540-5907.2007.00238.x.

Turner, J. C. (1982). Towards a cognitive redefinition of a social group. In H. Tajfel (Ed.), Social identity and intergroup relations (pp. 15-40). Cambridge: Cambridge University Press. 
Turner, J. C., Hogg, M. A., Oakes, P. J., Reicher, S. D., \& Wetherell, M. S. (1987). Rediscovering the social group: Self-categorization theory. New York, NY: B. Blackwell.

Ullrich, J., \& Van Dick, R. (2007). The group psychology of mergers \& acquisitions: Lessons from the social identity approach. In C. L. Cooper, \& S. Finkelstein (Eds.), Advances in mergers \& acquisitions (Vol. 6, pp. 1-15). Bingley: Emerald Group Publishing Limited.

Unsworth, K. L., \& Fielding, K. S. (2014). it's political: How the salience of one's political identity changes climate change beliefs and policy support. Global Environmental Change, 27(Supplement C), 131137. https://doi.org/10.1016/j.gloenvcha.2014.05.002.

Uzzell, D., Pol, E., \& Badenas, D. (2002). Place identification, social cohesion, and enviornmental sustainability. Environment and Behavior, 34(1), 26-53. https://doi.org/10.1177/0013916502034001003.

Van Dick, R. (2001). Identification in organizational contexts: Linking theory and research from social and organizational psychology. International Journal of Management Reviews, 3(4), 265-283. https://doi. org/10.1111/1468-2370.00068.

Van Dick, R., Wagner, U., Stellmacher, J., \& Christ, O. (2005). Category salience and organizational identification. Journal of Occupational and Organizational Psychology, 78(2), 273-285. https://doi. org/10.1348/096317905X25779.

Van Zomeren, M., Postmes, T., \& Spears, R. (2008). toward an integrative social identity model of collective action: A quantitative research synthesis of three socio-psychological perspectives. Psycholgical Bulletin, 134(4), 504-535. https://doi.org/10.1037/0033-2909.134.4.504.

Vogeler, C. S. (2018). Why do farm animal welfare regulations vary between EU member states? A comparative analysis of societal and party political determinants in France, Germany, Italy, Spain and the UK. JCMS: Journal of Common Market Studies. https://doi.org/10.1111/jcms.12794.

Vogeler, C. S., \& Bandelow, N. C. (2018). Mutual and self perceptions of opposing advocacy coalitions: Devil shift and angel shift in a German policy subsystem. Review of Policy Research. https://doi. org/10.1111/ropr.12299.

Walsh, K. C. (2004). Talking about politics: Informal groups and social identity in American life (Studies in communication, media, and public opinion). Chicago: University of Chicago Press.

Wang, K., \& Dovidio, J. F. (2016). Perceiving and confronting sexism. Psychology of Women Quarterly, 41(1), 65-76. https://doi.org/10.1177/0361684316670628.

Weible, C. M., \& Sabatier, P. A. (Eds.). (2017). Theories of the policy process (4th ed.). Boulder, CO: Westview Press.

Westfall, J., Van Boven, L., Chambers, J. R., \& Judd, C. M. (2015). Perceiving political polarization in the United States: party identity strength and attitude extremity exacerbate the perceived partisan divide. Perspectives on Psychological Science, 10(2), 145-158. https://doi.org/10.1177/1745691615569849.

Wieseke, J., Ahearne, M., Lam, S. K., \& van Dick, R. (2009). The role of leaders in internal marketing. Journal of Marketing, 73(2), 123-145.

Winterich, K. P., Zhang, Y., \& Mittal, V. (2012). How political identity and charity positioning increase donations: Insights from moral foundations theory. International Journal of Research in Marketing, 29(4), 346-354. https://doi.org/10.1016/j.ijresmar.2012.05.002.

Woisetschläger, D. M., Hartleb, V., \& Blut, M. (2008). How to make brand communities work: Antecedents and consequences of consumer participation. Journal of Relationship Marketing, 7(3), 237-256. https ://doi.org/10.1080/15332660802409605.

Zahariadis, N. (2003). Ambiguity and choice in public policy: Political decision making in modern democracies (American governance and public policy series). Washington, DC: Georgetown University Press.

Zohlnhöfer, R., Herweg, N., \& Rüb, F. W. (2015). Theoretically refining the multiple streams framework: An introduction. European Journal of Political Research, 54(3), 412-418. 